\title{
STUDI GERAK ANIMASI CARTOONY SEBAGAI PERANCANGAN ANIMASI PENDEK BERTEMA TRADISI DAN BUDAYA TIONGHOA
}

\author{
Stevani $^{1)}$, Frans Santoso ${ }^{2)}$ \\ School of Design, Universitas Bina Nusantara \\ Jl. K. H. Syahdan No. 9, Kemanggisan, Palmerah, Jakarta 11480, Indonesia \\ ${ }^{1}$ stevaniwillyanto@gmail.com, 2frans@binus.ac.id
}

\begin{abstract}
Abstrak
Setiap animasi di dalam dunia industri ingin memunculkan keunikan dari proyek yang dapat ditonjolkan melalui style animasi serta visual yang unik agar dapat bersaing dengan kompetitor lain. Terdapat berbagai macam style animasi cartoony, dan masing-masing memiliki keunikan yang berbeda-beda. Dalam perancangan laporan, akan dilakukannya riset gerak cartoony dengan tema dari konten lokal Indonesia sebagai inspirasi. Di Indonesia sudah mulai banyak film animasi baru yang terkenal. Namun, belum ada film animasi dari Indonesia dengan menggunakan budaya dan tradisi dari etnis Tionghoa. Oleh karena itu, penelitian ini bertujuan untuk mempelajari gerak cartoony sebagai perancangan di dalam film animasi pendek bertema tradisi dan budaya Tionghoa. Untuk mendapat hasil studi gerak dan visual sesuai dengan tujuan tersebut, metode penelitian yang akan digunakan untuk pencarian data dalam kajian ini adalah melalui literatur yang bersangkutan, observasi dan wawancara. Hasil atau output yang direncanakan berupa workbook visual yang akan digunakan untuk keperluan tugas akhir dalam merancang animasi pendek.
\end{abstract}

Keywords: studi gerak, cartoony, Tionghoa, workbook visual, animasi pendek

\begin{abstract}
Every animation industry in the world is willing to show their project uniqueness that can be shown through their animation style along with unique visual so they will be able to compete with others. There are a lot of cartoony animation styles, and each of them has its own unique features. In the process of making this proposal, there will be research about cartoony animation movement with the theme taken from Indonesian local content as an inspiration. In Indonesia, there is a lot of new animation film published that are famous. However, there had not been an animation film from Indonesia that features the culture and tradition from Tionghoa ethnicity. Therefore, the goal of this research is to study more about the cartoony animation movement in the process of making a short animation film with Tionghoa tradition and culture as the following theme. To get the result of movement studies and visuals that correspond with the goal, research methods to gather data that are applied includes study from relevant literature, observation, and interviews. The result or output is a visual workbook that will be used in the making of short animated films as the final project.
\end{abstract}

Kata Kunci: Movement study, cartoony, Tionghoa, visual workbook, short animation

\section{PENDAHULUAN}

Secara garis besar terdapat 2 jenis style gerak dalam animasi, yaitu gerak animasi realistic dan cartoony. Ansara (2015) dalam tesisnya menyatakan bahwa "Both realistic and cartoon 
animation are frequently used in the entertainment industry for advertisements, cartoons, live action movies, animated movies, and video games". Style animasi realistik berfokus dalam menciptakan gerakan seperti dunia nyata, berbeda dengan cartoony yang kontras dengan realistic, gerak seperti ini tidak dapat diwujudkan dalam dunia nyata. Oleh karena itu, style gerak animasi cartoony lebih umum digunakan dalam kartun anak-anak karena lebih menarik. Masing-masing proyek dari animasi cartoony memiliki keunikan yang membuat animasi tersebut berbeda dari yang lain. Setiap animasi di dalam dunia industri ingin memunculkan keunikan dari proyek yang dikerjakan agar dapat bersaing dengan kompetitor yang lain. Keunikan tersebut dapat ditonjolkan melalui style animasi yang unik dan visual yang menarik. Oleh karena itu, penulis akan meneliti style animasi cartoony yang menggunakan stepped key agar lebih spesifik, konsisten, dan tidak terlalu meluas. Alasan penulis memilih stepped key, dapat dilihat dari artikel website Pluralsight yang membahas perbedaan step dan spline key. Menurut Pluralsight (2014), "Often times, when converting an animation from stepped to spline, animators run into a problem where the animation becomes like mush, and it doesn't have the same snappiness as before. That's because each transition is happening over a single frame, once you have the computer interpolate between those keyframes, it can really slow things down and the animation won't have the same feeling as before". Dengan menggunakan stepped key, animasi yang dibuat akan lebih cepat dalam segi produksi serta dapat membuat efek animasi lebih snappy. Referensi animasi step dengan visual yang sesuai sebagai referensi adalah animasi Spookiz, Umio, dan Hedgehog.

Untuk tema cerita, penulis akan mengangkat unsur-unsur budaya dan tradisi dari etnis Tionghoa sebagai inspirasi cerita. Alasan penulis memilih tema ini dikarenakan belum pernah ada film animasi dari Indonesia yang merepresentasikan budaya dan tradisi dari etnis Tionghoa. Dari segi visual, penulis akan mengambil referensi dari kuil dan patung di kelenteng, serta referensi style visual 2D yang cocok untuk gerak cartoony yang menggunakan stepped key. Berdasarkan dari tema dan style tersebut, penulis ingin melakukan analisa style gerak cartoony bertema tradisi dan budaya Tionghoa. Dengan menggunakan gerak animasi dengan style yang telah terkenal, diharapkan agar masyarakat Indonesia yang menonton menikmati konten budaya Indonesia yang diberikan. Diharapkan animasi pendek ini dapat menghibur, menginspirasi, dan memajukan industri animasi Indonesia.

\section{Kajian Literatur \\ Animasi}

Animasi awalnya berasal dari bahasa latin "anima" yang berarti jiwa, atau hidup, sedangkan dalam bahasa inggris berasal dari kata "to animate" yang berarti menggerakkan atau menghidupkan. Menurut Fernandes (2001), penulis Macromedia Flash Animation \& Cartooning: A creative Guide, "Animation is the process of recording and playing back a sequence of stills to achieve the illusion of continues motion". Hwang, I., Tam, M., Lam, S. L., dan Lam, P. (2012) dalam jurnalnya menyatakan bahwa "animation can be applied in the study of physiology, such as presenting modules covering the muscular, respiratory, urinary, cardiovascular and nervous systems." Selain mempermudah dalam menggambarkan suatu ide atau konsep, animasi juga dapat menjadi media penyampaian pesan dan tuntunan yang dikemas secara menarik untuk anak-anak.

\section{Teori Prinsip Dasar Animasi 3D}

Berbeda dengan animasi 2D yang menggunakan gambar, animasi 3D menggunakan model 3D. Menurut Catmull (1972), penulis A System for Computer Generated Movies, "3D animations were script-based with few spline-interpolated keyframe systems". Kedatangan sistem animasi keyframe dapat diwujudkan pertama kali dengan perusahaan-perusahaan besar seperti Abel Image Research, Alias Research Inc., and Wavefront Technologies Inc. Namun dengan sistem teknologi yang canggih, animasi yang dihasilkan kurang memuaskan. Menurut Lasseter (1987), penulis Principles of Traditional Animation Applied to 3D Computer Animation, "In the late 1920s and 1930s animation was developed from an innovation to a fine art form by the Walt Disney Studios. They set up drawing classes at the Chouinara Art Institute in Los Angeles spearheaded by Don Graham. Here the students/animators learned the standardized formula of old cartoons which 
lead to the discovery of ways of drawing moving figures and humans". Sehingga Lasseter menyadari bahwa dalam menggerakan animasi 3D, tetap diperlukannya pengaplikasian teori dasar animasi yang telah digunakan dalam animasi 2D Disney di zaman itu.

Dalam teori dasar, animasi memiliki 12 prinsip animasi. Meski awalnya diperkenalkan oleh Disney untuk 2D animation, 12 prinsip animasi ini masih menjadi menterjemahkan dalam penganimasian animasi 3D. Dari 12 prinsip animasi, penulis hanya berfokus dan menganalisis 6 karena 6 prinsip ini yang paling menonjol dan penting dari style gerak yang akan di analisa. 6 prinsip animasi tersebut adalah sebagai berikut:

1. Timing: Menurut Halas dan Whitaker (1981), penulis Timing for Animation, "Timing is the gapping of actions to describe the weight and size of figures and the personality of characters". Timing menandakan aksi dalan sebuah animasi dipikirkan dan direncanakan dengan baik. Timing yang benar akan menjadi unsur penting dalam membuat ide yang lebih jelas. Jika timing terlalu lambat, animasi akan menjadi membosankan. Namun, jika terlalu cepat, tidak akan jelas apa yang ingin disampaikan.

2. Squash \& Stretch: Squash \& Stretch adalah penambahan gerakan dinamis pada objek atau figur sehingga seolah-olah 'memuai' atau 'menyusut' sehingga memberikan efek gerak yang lebih hidup. Menurut Thomas dan Johnston (1981), penulis Disney Animation-The Illusion of Life, "The squashed position represents the form either flattened out by an external pressure or constricted by its own power. The stretched position constantly shows the same form in a muchextended condition". Namun hal terpenting yang harus diketahui adalah "no matter how squashed or stretched out a particular object gets, its volume remains constant".

3. Anticipation: Anticipation adalah persiapan/awalan gerak. Menurut Thomas dan Johnston (1981), penulis Disney Animation-The Illusion of Life, "The 'what is he going to do next?' Question is critical", sehingga antisipasi mungkin tidak akan memberikan informasi mengapa karakter bergerak demikian, tatapi penonton mengetahui bahwa akan adanya gerakan yang akan terjadi. Antisipasi digunakan sebagai cara untuk mendapatkan perhatian penonton, dan mempersiapkan mereka untuk gerak berikutnya. Contoh penggunaan antisipasi adalah saat seseorang yang bangkit dari duduk harus membungkukkan badannya terlebih dahulu sebelum benar-benar berdiri. Pada gerakan melompat, seseorang yang tadinya berdiri harus ada gerakan 'membungkuk' terlebih dulu sebelum akhirnya melompat. Menurut William (2009), penulis The Animators Survival Kit, "There are only three things in animation, 1 Anticipation, 2 - Action, 3 - Reaction". Dengan mengapilkasikan ketiga ini, maka animator dapat animasi dengan baik. Setiap gerakan yang akan dilakukan akan direncanakan dan dipikirkan dulu sebelum dilakukan, sehingga membutuhkan anticipation. Setelah dilakukan, maka adanya akibat dari aksi tersebut.

4. Arcs: Arc adalah jalur visual dari suatu objek. Arc menjadi alat penting dalam membuat gerakan terlihat realistik dan indah. Ada 2 jenis arc yaitu linear dan circular. Umumnya arc yang sering digunakan dalam karakter berbentuk circular/lengkung (termasuk lingkaran, elips, atau parabola) karena membuat gerak lebih organik. Hal ini juga disebabkan karena makhluk hidup memiliki sendi. Linear arc digunakan untuk gerak mekanik seperti gerak pada robot.

5. Staging: Staging merupakan susunan ide secara keseluruhan dan dengan jelas. Menurut Thomas dan Johnston (1981), penulis Disney Animation-The Illusion of Life, "For better understanding, action is staged. For easy recognition, personality is staged. To affect the mood of the audience, expressions and moods are staged". Di dalam animasi, aksi harus dilakukan satu per satu, jika terlalu banyak aksi yang terjadi, maka penonton akan bingung dan tidak tahu bagian mana yang harus difokuskan.

6. Exaggeration: Exaggeration diperlukan dalam animasi untuk menekankan dan memperjelas sebuah aksi yang terjadi. Contohnya, untuk membuat adegan sebuah karakter kaget atau terkejut, exaggeration yang digunakan adalah dengan menonjolkan bola mata karakter tersebut keluar dari kantong matanya, dimana hal ini dalam dunia nyata adalah sesuatu yang mustahil terjadi. Dalam membuat sebuah ide atau cerita dalam sebuah adegan, agar cerita 
tersebut terlihat lebih menarik, diperlukan exaggeration. Kepribadian sebuah karakter dapat ditunjukkan dengan lebih jelas dengan animasi yang exaggerating.

\section{Style Gerak Animasi Cartoony}

Ansara (2015) dalam thesisnya menyatakan bahwa "Both realistic and cartoon animation are frequently used in the entertainment industry for advertisements, cartoons, live action movies, animated movies, and video games". Style animasi realistic berfokus dalam menciptakan gerakan seperti dunia nyata, berbeda dengan cartoony yang kontras dengan realistic sehingga karakter dapat squish, squash, stretch yang dimana gerak seperti ini tidak dapat diwujudkan dalam dunia nyata.
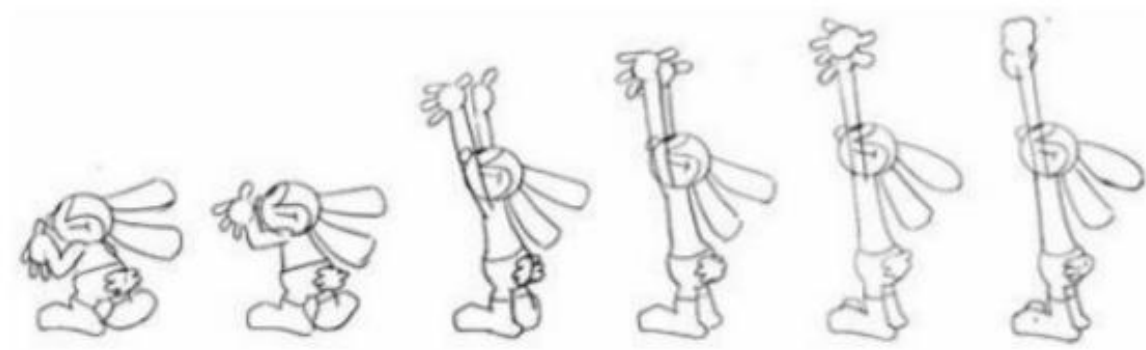

Gambar 1 Stretch dalam tubuh dan tangan karakter Oswald

Seperti yang bisa kita lihat dari gambar 1, tubuh pada karakter kartun tidak dibatasi dengan hukum dasar fisika, tetapi bedasarkan keputusan artistik animator. Exaggerated movements akan memunculkan emphasis terhadap aksi di dalam animasi untuk menyampaikan emosi atau untuk menghasilkan efek komedi/dramatis.

Dalam style gerak cartoony, pose master stories sehingga akan sangat penting bagi animator untuk menentukan pose yang baik. Pose secara garis besar merupakan representasi visual dari sebuah idea dalam bentuk. Selain itu, pose juga memperkuat staging / komposisi sebuah adegan. Dalam membuat pose karakter cartoony 3D, tetap diperlukannya gambaran dan referensi animasi cartoony 2D sehingga pose dalam karakter 3D dapat di kembangkan kembali ke gaya yang lebih dinamis. Dalam pose tetap ada penggunaan prinsip animasi.

\section{Perbedaan Stepped dan Spline key}

Di artikel online mengenai Stepped Vs. Spline Curves When Blocking an Animation, oleh Pluralsight (2014), dijelaskan perbedaan step dan spline di animasi, serta manfaatnya. Pada workflow animasi pada umumnya, animator blocking menggunakan stepped key, kemudian di spline jika telah selesai. Kedua spline dan step mengacu bagaimana sisipan di antara kedua key di animasi. Stepped berarti tidak ada animasi yang dibuat di antara dua key pose, sedangkan dengan spline komputer akan secara otomatis membuat inbetween diantara dua key pose. Manfaat menggunakan step ketika blocking, maka animator dapat lebih fokus dalam membuat key di animasi karena software tidak secara otomatis memasukkan animasi di antara keyframe. Manfaat dengan animasi menggunakan spline, animasi dapat dilakukan dengan straight ahead dan organik, serta animator sudah mengetahui bagaimana timing animasi dalam shot. Namun, jika menggunakan teknik animasi straight ahead, animator sulit menentukan pose yang baik. Oleh karena itu, lebih ideal dan cocok untuk animator yang baru belajar menggunakan teknik pose to pose dengan membuat key dengan step curves saat blocking, kemudian spline saat selesai. Namun, terkadang saat stepped key diubah menjadi spline, timing semakin pelan dan berubah, yang membuat energinya berkurang, terutama untuk gerakkan cepat (Pluralsight, 2014). Sehingga untuk menghemat waktu produksi serta mempertahankan feel dari animasi, beberapa proyek animasi tetap menggunakan stepped key. 


\section{Tradisi dan budaya Tionghoa}

Suku Tionghoa adalah salah satu etnis di Indonesia yang asal usul leluhur mereka berasal dari Tiongkok (China). Dalam bahasa Mandarin mereka disebut Tangren dikarenakan sesuai dengan kenyataan bahwa orang Tionghoa mayoritas berasal dari Tiongkok selatan yang menyebut diri mereka sebagai orang Tang, sementara orang Tiongkok utara menyebut diri mereka sebagai orang Han. Leluhur orang Tionghoa berimigrasi secara bergelombang sejak ribuan tahun yang lalu melalui kegiatan perniagaan. Setelah negara Indonesia merdeka, orang Tionghoa yang berkewarganegaraan Indonesia digolongkan sebagai salah satu suku dalam lingkup nasional Indonesia, sesuai Pasal 2 UU Nomor 12 Tahun 2006 tentang Kewarganegaraan Republik Indonesia. Suku Tionghoa di Indonesia yang menganut kepercayaan tradisional Tionghoa dan masih menjalankan tradisi, umumnya pergi beribadah ke kelenteng. Istilah Kelenteng diambil dari bunyi suara lonceng yang dibunyikan pada saat menyelenggarakan upacara. Pada mulanya, kelenteng adalah tempat penghormatan pada leluhur atau dewa, masing-masing marga. Para dewa-dewi yang dihormati tentunya berasal dari suatu marga tertentu yang pada awalnya dihormati oleh marga mereka. Seiring perkembangan zaman, penghormatan kepada dewa-dewi yang kemudian dibuatkan ruangan khusus yang dikenal sebagai kelenteng yang dapat dihormati oleh berbagai macam marga, suku. Kelenteng selain sebagai tempat penghormatan para leluhur, para dewa-dewi, dan tempat mempelajari berbagai ajaran, juga digunakan sebagai tempat yang damai untuk semua golongan tidak memandang dari suku dan agama apapun. Di kelenteng, suku Tionghoa sembahyang kepada dewa dengan hio. Pada umumnya umat Tionghoa membawa kertas, bunga dan makanan persembahan ke kelenteng sebagai ucapan terima kasih terhadap dewa/dewi. Segala bentuk persembahan ditaruh di meja altar persembahan dewa. Salah satu dewa kepercayaan Tionghoa yang akan digunakan penulis sebagai referensi adalah dewa Guan Yu. Guan Yu bedasarkan nama sejarahnya, dikenal juga sebagai Kwan Gong/Guandi/Wudi. Walaupun Guan Yu merupakan dewa perang, ia terkenal karena merupakan penjaga kedamaian dan harmoni, bukan perang. "He is more often worshipped as man of peace and guarantor of harmony than a simple God of War. He only became a soldier to try and prevent the country falling into chaos and to restore the land to peace" (Strippedpixel, 2013).

\section{Existing Study}

\section{Studi style gerak animasi Spookiz}

Spookiz merupakan serial animasi 3D berasal dari Korea dengan genre komedi yang tayang di Disney. Spookiz merupakan animasi dengan style gerak cartoony yang cukup terkenal keunikannya di industri animasi. Dengan menggunakan style gerak cartoony, maka animasi yang dibuat penulis akan cocok untuk target audience penulis, yaitu anak-anak. Pose menjadi unsur penting dalam karakter. Namun, keunikan dalam style animasi Spookiz, tetap digunakannya stepped key sebagai hasil akhir dari animasi, karena terkadang saat stepped key diubah menjadi spline, timing semakin pelan dan berubah, yang membuat energinya berkurang, terutama untuk gerakkan cepat. Oleh karena itu, dalam proyek Spookiz, digunakannya stepped key agar tetap snappy dan gerakan terlihat lebih cepat. Selain itu, hal ini juga mempercepat proses produksi. Namun dalam Spookiz tidak secara keseluruhan menggunakan step key di setiap gerakan. Pada umumnya, animasi dengan step key, jika gerakan kecil, animasi akan terlihat kaku atau patahpatah. Oleh karena itu, animasi Spookiz menggunakan spline key di beberapa gerakan kecil, contohnya seperti ekspresi, agar animasi tidak terlalu kaku. Inilah yang menjadi keunikan penggunaan stepped key di animasi Spookiz. Namun, berbeda dari animasi yang penulis rancang, Spookiz tidak menggunakan render 2D sehingga animasi yang dibuat penulis akan berbeda.

\section{Studi style gerak animasi Umio}

Umio merupakan animasi pendek dengan tema "Love" dari mahasiswa Gobelins karya Marine Varguy tahun 2017. Aplikasi 3D yang digunakan dalam animasi ini adalah Maya. Animasi ini menggunakan stepped key yang didukung dengan render toon dan latar belakang yang berbentuk 2D. Animasi ini memiliki style visual yang cocok untuk perancangan animasi penulis, namun 
kekurangan dari animasi ini adalah gerakan yang terlalu kaku karena terlalu banyak frame di antara key yang step, serta pose dan gerak kurang cartoony. Kurang cartoony dapat terlihat dari kurangnya penggunaan exaggeration di dalam gerak. Sehingga penulis akan menggunakan visual animasi ini didukung referensi dari gerak dari animasi Spookiz, agar lebih terlihat cartoony.

\section{Studi style gerak animasi Hedgehog}

Hedgehog merupakan animasi pendek 3D karya Vaibhav Keswani, Jeanne Laureau, dan Colombine Majou tahun 2018. Animasi ini menggunakan stepped key yang didukung dengan render toon dan latar belakang yang berbentuk 2D. Sama seperti Umio, animasi ini memiliki style visual yang cocok untuk perancangan animasi penulis. Untuk gerak juga lebih halus jika dibandingkan Umio karena banyak jumlah frame diantara key tidak terlalu banyak sehingga tidak terlalu kaku. Namun, pose dan gerakan kurang cartoony karena cerita dari animasi ini yang memiliki genre berupa drama dan sedih. Penulis akan menggunakan gerak dan visual animasi ini didukung referensi dari gerak dari animasi Spookiz, agar lebih terlihat cartoony.

\section{Studi cerita animasi Baozha}

"Baozha" adalah animasi pendek karya Jasper Liu, Bryan Goo dan Jolene Cheng. Animasi Baozha menggunakan kepercayaan China, yang dimana juga merupakan kepercayaan etnis Tionghoa di Indonesia. Animasi pendek ini juga menggunakan dewa/dewi sebagai karakternya sehingga dapat dijadikan referensi tambahan. Namun, point of view dari animasi ini adalah si dewa yang senang sekali bermain game, namun memiliki tugas untuk melindungi si nenek. Animasi ini menggambarkan budaya dan kepercayaan Tionghoa bahwa dewa ataupun dewi memiliki suatu sifat dan interpretasi. Dewa atau dewi memiliki peran untuk melindungi penganutnya.

\section{Studi cerita animasi Little Stone Lion}

"Stone Lion" adalah animasi pendek karya Wu Zang Miao. "Little Stone Lion" menceritakan patung dewa di kuil/kelenteng yang dapat bergerak untuk melindungi makanan kelenteng dari kucing liar. Goals karakter ini menjadi referensi menarik bagi penulis, yaitu merebut makanan. Namun, yang terpenting dari cerita animasi Little Stone Lion adalah ending dari ceritanya, si kucing tidak mendapatkan makanan yang diinginkan, tetapi tetap dibantu oleh patung dewa untuk mendapatkan makanan. Ending dari animasi ini memberikan pelajaran dan kebahagiaan kedua karakter.

\section{Studi cerita animasi Tiger God}

"Tiger God" adalah animasi pendek karya Hu Ye Shan. Di dalam animasi pendek "Tiger God", point of view adalah dari si anak kecil yang sedang mencoret-coret dinding di kuil. Hal ini menyebabkan ia diserang oleh makhluk jahat sehingga patung dewa di kuil melindungi dia. Berbeda dari referensi lain yang mengambil point of view dari patung dewa, dengan mengambil point of view dari anak kecil akan memunculkan rasa penasaran dan sesuatu yang tidak disangka oleh pentonton. Hal ini juga digunakan dalam animasi pendek Sanjay's Super Team oleh Pixar. Oleh karena itu, penulis juga akan merancang animasi pendek dari point of view anak kecil agar penonton bisa mengetahui informasi, sama seperti karakter utama untuk meningkatkan kemenarikan.

\section{METODE PENELITIAN}

Metode penelitian yang digunakan penulis adalah cara kualitatif. Penelitian kualitatif bersifat deskripsi, cenderung menggunakan analisis dan lebih menampakkan proses maknanya. Tujuan dari metode ini adalah untuk memahami secara luas dan mendalam terhadap suatu masalah secara detail pada suatu permasalahan yang sedang dikaji. Penulis memilih penelitian ini dikarenakan dalam segi pengumpulan data akan gerak cartoony, cukup dengan observasi, studi kepustakaan, dan wawancara dengan animator professional, karena dalam riset mengenai gerak cartoony, diperlukannya ahli yang telah mengeti perbedaan gerak animasi cartoony dengan yang realistik. 
Visual dan tema pun cukup dengan kualitatif karena hanya sebagai pendukung atas gerak cartoony. Berikut ini teknik pengumpulan data yang dilakukan penulis:

\section{Riset Observasi}

Penulis akan melakukan pengumpulan data dengan observasi gerak, pose, dan ekspresi yang dilakukan anak kecil serta gerakan patung dewa melalui referensi yang bisa diambil dari animasi, illustrasi, film, bahkan foto dari dunia nyata. Penulis akan mengobservasi ciri-ciri gerak cartoony dan animasi dengan stepped key dari referensi yang telah ditentukan. Penulis akan melakukan observasi ke kelenteng secara langsung untuk mendapatkan inpirasi dalam mendesain visual dalam animasi pendek ini.

\section{Studi Kepustakaan}

Penulis akan meneliti gerakan cartoony serta keunikannya, didasari dari 12 prinsip dasar animasi dan teori lain yang berhubungan. Perancangan visual dari desain karakter, warna, bahkan dalam pembuatan cerita akan didukung dari teori desain komunikasi visual yang bersangkutan. Penulis dapat melakukan pengumpulan data dari buku-buku, website, maupun laporan yang berhubungan dengan karakteristik gerakan cartoony dan penerapannya sesuai dengan prinsip dasar animasi. Penulis juga akan meneliti adat dan budaya etnis Tionghoa sebagai inspirasi cerita dan desain visual di dalam perancangan animasi pendek ini.

\section{Wawancara}

Dalam penelitian ini, penulis akan mewawancarai animator profesional mengenai workflow, cartoony animation, penerapan prinsip dasar animasi, pose dan cara menyampaikan komedi melalui gerak. Animator yang penulis wawancarai adalah Jeremy Hidayat. Beliau sudah 6 tahun bekerja sebagai animator 3D. Beliau telah mengerjakan projek animasi internasional seperti Franklin and Friends, Peter Rabbit, Insectibles, dan Oddbods. Sekarang beliau sedang bekerja di Ubisoft Singapura. Wawancara dengan animator akan mendukung penelitian penulis dalam segi gerak animasi cartoony. Dalam segi desain, penulis akan mewawancarai art director serta visual development artist Andrey Pratama. Beliau terkenal dengan karyanya Moriendo, dan telah 6 tahun bekerja secara profesional di industri animasi. Dalam segi cerita, penulis akan mewawancarai pembina kelenteng Sukianto Samin dan penjaga kelenteng Yusuf untuk memahami lebih dalam adat dan budaya etnis Tionghoa sebagai inspirasi cerita.

\section{Metode Perancangan}

Metode perancangan yang digunakan penulis adalah 7 tahap proses desain. Menurut Ambrose dan Harris (2010), 7 tahap ini merupakan tahap penting dalam merancang suatu desain, namun dalam penelitian ini, penulis hanya menyelesaikan sampai tahap prototype, yaitu pembuatan workbook karena belum dibuat hasil akhir yaitu animasi pendek. Berikut ini tahap proses desain dalam perancangan workbook:

\section{Define}

Proses ini adalah tahap pertama dalam setiap proses desain, tahap dimana perancang mengambil masalah, yang kemudian akan menghasilkan berbagai alternatif solusi yang sesuai. Penulis mengambil riset gerak animasi cartoony dengan step key animation. Namun penulis belum mengerti secara dalam animasi seperti ini karena kurangnya pengalaman, serta belum banyak jurnal ataupun artikel yang membahas mengenai animasi seperti ini. Oleh karena itu, penulis perlu meneliti banyak mengenai gerak ini. Gerakan cartoony ini juga harus didukung tema dan visual yang sesuai. Penulis memilih tema budaya dan tradisi Tionghoa sebagai inspirasi cerita karena belum banyak animasi Indonesia dengan tema ini. Target audience adalah anak SD berusia 7-12 tahun sehingga desain visual harus disesuaikan dengan target audience.

\section{Research}


Setelah masalah telah didefinisikan, desainer mulai mencari informasi yang dapat diolah ke dalam proses kreatif selanjutnya, ideate. Riset yang akan dilakukan penulis dalam perancangan workbook ini adalah riset observasi, studi kepustakaan, dan wawancara. Penulis akan melakukan pengumpulan data dengan observasi yang bisa diambil dari animasi, illustrasi, film, bahkan foto dari dunia nyata. Penulis akan observasi ciri-ciri gerak cartoony dan animasi dengan stepped key dari referensi animasi yang telah ditentukan. Penulis akan melakukan observasi ke kelenteng secara langsung untuk mendapatkan inpirasi dalam mendesain visual dalam animasi pendek ini. Untuk studi kepustakaan, dari style gerak, desain karakter, warna, bahkan dalam pembuatan cerita akan didukung dari teori desain komunikasi visual yang bersangkutan. Penulis dapat melakukan pengumpulan data dari buku, website, dan jurnal yang berhubungan dengan karakteristik gerakan cartoony dan penerapannya sesuai dengan prinsip dasar animasi. Penulis juga akan meneliti adat dan budaya etnis Tionghoa sebagai inspirasi cerita dan desain visual di dalam perancangan animasi pendek ini. Dalam penelitian ini, penulis akan mewawancarai animator profesional untuk pemahaman lebih dalam mengenai gerak cartoony terutama dengan style yang telah ditentukan, yang didukung dengan wawancara dengan art director/visual development artist, agar mengetahui cara merancang visual dari ide yang telah ditentukan. Untuk mendapat inspirasi cerita, penulis akan mewawancarai pembina kelenteng.

\section{Ideate}

Tahap ini perancang mencari solusi terhadap masalah yang telah ditentukan. Informasi yang dikumpulkan di tahap research digunakan untuk membuat gagasan atau ide untuk rancangan desain. Oleh karena itu, penulis akan menganalisis hasil riset dan meringkasnya. Dalam menemukan solusi, penulis telah mengumpulkan data dari hasil riset sehingga penulis dapat memulai membuat alternatif desain. Penulis juga mulai membuat alternatif desain untuk menentukan hasil desain akhir yang diinginkan.

\section{Prototype}

Tahap ideate menghasilkan berbagai solusi dan ide yang berpotensi untuk menghasilkan desain yang sesuai. Hasil atau output akhir yang menjadi prototype berupa alternatif visual dari desain karakter, pose gerak, desain latar, storyboard, concept art, dan moodboard. Semua desain akan didasari dari solusi yang telah ditentukan dalam tahap Ideate yang akan disusun ke dalam workbook.

\section{HASIL DAN PEMBAHASAN}

\section{Data Hasil Riset Observasi}

Penulis melakukan riset observasi pose dalam animasi cartoony dan step animation. Penulis juga melakukan observasi di kelenteng Dharma Bhakti dan Lho She Kong untuk mengambil image chart dan inspirasi desain visual. Berikut ini hasil survei penulis terhadap pose dalam animasi cartoony dan step animation:

1. Siluet dari pose dalam animasi cartoony penting dalam menyampaikan ekspresi. Tanpa memperlihatkan ekspresi wajah, penonton harus dapat mengetahui sifat dan ekspresi dari karakter.

2. Pose dalam animasi cartoony mementingkan estetika. Bisa dilihat dari pose karakter dari animasi Spookiz pada gambar 2, pose karakter jika di dunia nyata maka karakter akan jatuh,

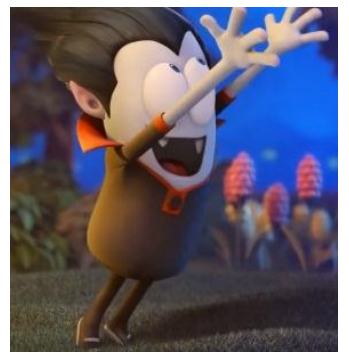


namun asalkan pose terlihat exaggerate dan indah, maka pose tidak akan menjadi masalah di animasi cartoony.

Gambar 2 Pose karakter animasi Spookiz

3. Pose dalam gerakan animasi cartoony terdapat squash and stretch. Berikut ini contoh pose breakdown dalam animasi Spookiz.
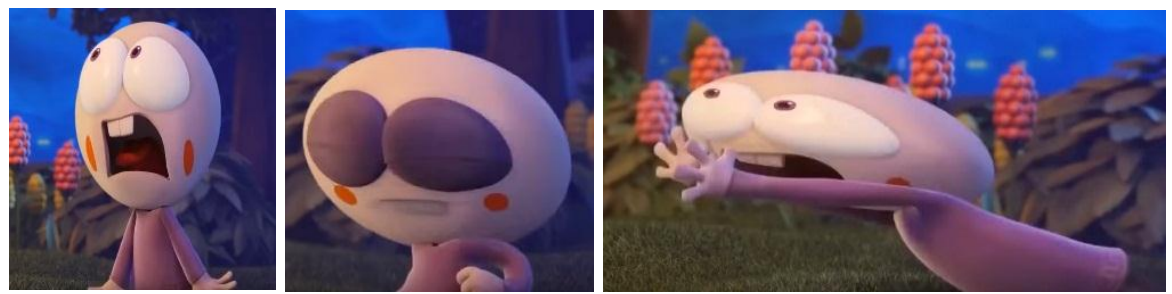

Gambar 3 Pose breakdown animasi Spookiz

4. Dari referensi animasi Hedgehog dan Umio, render 2D cocok untuk animasi dengan step animation, namun dari satu pose ke pose lain dalam animasi step harus kurang dari 4 frame, jika lebih maka animasi terlihat terlalu patah-patah.

5. Makin besar jumah frame dari pose ke pose, maka gerakan semakin snappy. Oleh karena itu, jika gerakan besar, maka jumlah frame lebih besar untuk menciptakan efek snappy. Jika gerakan kecil, maka semakin kecil jumlah frame agar gerakan tidak terlihat patah-patah.

Hasil observasi tempat dilakukan untuk menjadi referensi desain visual. Foto hasil observasi akan dilampirkan di lampiran. Berikut ini beberapa hasil foto hasil riset observasi di kelenteng Dharma Bhakti dan Lho She Kong:
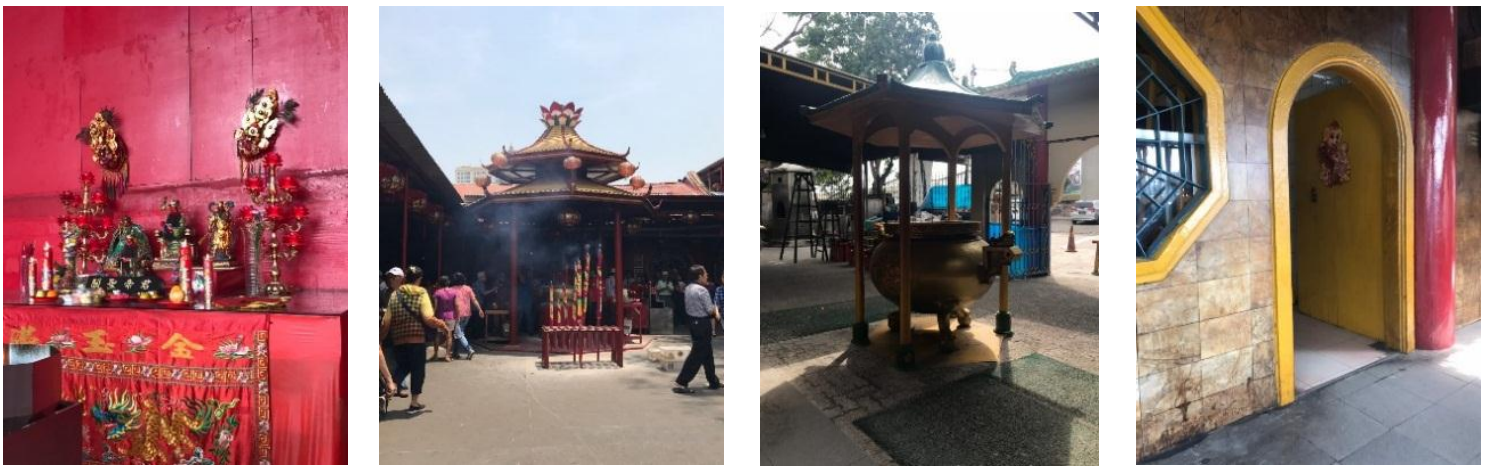

Gambar 4 Gambar hasil riset observasi

\section{Data Hasil Studi Kepustakaan}

Berikut ini hasil dari studi kepustakaan penulis:

1. Style animasi realistic berfokus dalam menciptakan gerakan seperti dunia nyata, berbeda dengan cartoony yang tidak dapat diwujudkan dalam dunia nyata.

2. Dalam style gerak cartoony, pose master stories sehingga akan sangat penting bagi animator untuk menentukan pose yang baik.

3. Dalam mendesain karakter, bentuk dasar sangat penting dalam menyampaikan informasi mengenai karakter, namun perlu untuk mengetahui 'belief' dari karakter untuk memenuhi 'desires' agar karakter lebih dapat dipercaya penonton.

4. Saat stepped key diubah menjadi spline, timing semakin pelan dan berubah, yang membuat energinya berkurang, terutama untuk gerakkan cepat. Sehingga untuk menghemat waktu produksi serta mempertahankan feel snappy dari animasi, beberapa proyek animasi tetap menggunakan stepped key. 
Selain hasil yang diatas, penulis hanya menggunakan 5 teori karena beberapa belum dapat diterapkan keseluruhannya di dalam riset. Berikut ini hasil studi 5 teori dari 12 prinsip animasi dan penerapannya dalam animasi cartoony:

1. Exaggeration berperan penting dalam animasi cartoony. Semakin cartoony, maka pose dan gerakan semakin exaggerate, berbeda dengan dunia nyata yang lebih kurang exaggerate dan lebih realistik.

2. Squash \& stretch berperan penting dalam gerak animasi cartoony dan untuk menambahkan exaggeration. Biasanya squash \& stretch banyak digunakan sebagai pose inbetween. Squash \& stretch memberikan efek gerak yang lebih hidup

3. Arc dalam animasi cartoony dapat diterapkan di gerakan dan pose untuk menambahkan keindahan. Arc ada di dalam gerakan realistik dan dunia nyata, tetapidi cartoony arc lebih terlihat dan exagerrate karena lebih mengutamakan estetika.

4. Staging penting saat membuat storyboard dan beatboard. Segala penempatan perlu diatur agar pesan yang tersampaikan jelas ke penonton. Di dalam animasi, aksi harus dilakukan satu per satu, jika terlalu banyak aksi yang terjadi, maka penonton akan bingung dan tidak tahu bagian mana yang harus difokuskan.

5. Anticipation ada di dalam suatu gerak dan aktivitas. Antisipasi digunakan sebagai cara untuk mendapatkan perhatian penonton, dan mempersiapkan mereka untuk gerak berikutnya. Setiap gerakan yang akan dilakukan akan direncanakan dan dipikirkan dulu sebelum dilakukan, sehingga membutuhkan anticipation. Hal ini penting dalam membuat perencanaan gerak dalah storyboard.

\section{Data Hasil Wawancara}

Hasil wawancara dengan animator

Jeremy Hidayat bekerja di Ubisoft Singapura. Selama di Indonesia, beliau lebih banyak mengerjakan proyek luar negeri. Proyek yang pernah dikerjakan beliau diantaranya Franklin and Friends, Peter Rabbit, Insectibles, dan Oddbods. Wawancara dilakukan untuk mengetahui workflow animasi 3D serta animasi cartoony dan step animation lebih mendalam. Berikut ini kesimpulan dari hasil wawancara penulis:

1. Workflow animasi yang digunakan adalah pose to pose. Secara umum animator juga menggunakan pose to pose dengan step.

2. Observasi style animasi dapat dilakukan dengan mempelajarinya frame by frame, mempelajari animation bible, dan eksperimen sendiri

3. Animasi cartoony banyak memikirkan shape dan keindahan, sehingga tidak harus masuk akal asal bagus secara estetika. Gerakan realistic lebih body mechanic yang tidak menjadi keharusan di style cartoony.

4. Animasi cartoony lebih seru karena lebih ada kebebasan dan creativity. Namun penting untuk menghormati hukum-hukum di dunia nyata agar tetap relatable.

5. Dalam membuat exaggeration, cari referensi di dunia nyata agar lebih bisa dipercaya penonton. Exagerration mirip karikatur, tidak bisa semuanya di exaggerate dalam waktu bersamaan.

6. Worry about the timing, not the motion. Dalam menyampaikan story maupun komedi, timing harus tepat sama seperti comedian.

7. Dalam membuat animation bible yang baik, ask a lot of question.

8. Penggunaan step animation sudah digunakan sejak lama. Animator saat masih menggunakan cell animation, untuk mempermudah produksi, animasi menggunakan 12 FPS, sehingga animasi menjadi step. Animasi dengan step lebih terlihat snappy dan cepat. Bisa dilihat contoh film animasi Who Framed Roger Rabbit, animator yang terbiasa cell drawn harus menggunakan 24 FPS, animasi menjadi terlalu berlebihan. Namun belakangan ini, banyak yang memanfaatkan step animation menjadi style yang baru. Contohnya seperti Spiderman into Spiderverse dan Spookiz yang menggunakan step sehingga animasi menjadi snappy untuk gerakan cepat. 
9. "Good artist copy, great artist steal". Jangan mengikuti style animasi secara spesifik dan sama persis, kumpulkan banyak referensi, dan buatlah sesuatu yang baru.

Hasil wawancara art director dan visual development artist

Andrey Pratama merupakan art director serta visual development artist. Salah satu karyanya yang terkenal adalah Moriendo. Wawancara dilakukan untuk membahas dan mencari tahu lebih worlflow dalam mendesain visual untuk 3D. Berikut ini kesimpulan dari hasil wawancara penulis:

1. Style visual yang ingin dibuat bergantung dari message animasi yang ingin disampaikan.

2. Untuk membuat design character menarik adalah dengan membuat karakter sesuai dengan persepsi dan style kita bukan karena ingin terlihat seperti orang lain. Yakin dengan keputusan sendiri saat membuat karakter desain. Hampir tidak mungkin apa yang kita pikirkan pernah dipikirkan oleh orang lain. Jadi saran saya, buatlah karakter dimana kalian sendiri sebagai kreator "merasakan" karakter itu.

3. Dalam membuat konsep visual dan karakter desain, tidak harus mempertimbangkan desainnya agar dapat divisualisasikan ke dalam 3D karena konsep itu tidak boleh diberi batasan dan harus sekreatif mungkin.

4. Mengetahui batasan akan skill pribadi dan apa yang bisa diachieve oleh software $3 \mathrm{~d}$ tersebut.

5. Mengambil referensi visual dari literatur, buku-buku sejarah, lukisan-lukisan klasik, karya artist-artist dalam dan luar negeri.

Hasil wawancara dengan penjaga dan pembina kelenteng

Penulis mewawancarai Yunus sebagai penjaga kelenteng Vihara Dharma Bhakti dan Sukianto Samin sebagai pembina kelenteng Lho She Kong. Tujuan wawancara dilakukan sebagai pemahaman lebih mendalam atas adat Tionghoa dan inspirasi cerita. Berikut ini kesimpulan dari hasil wawancara penulis:

1. Kelenteng merupakan tempat beribadah bagi umat Konghucu. Terdapat berbagai macam rupang/patung dewa-dewi oleh berbagai macam marga, dibuatkanlah ruangan khusus yang dikenal sebagai Klenteng. Sementara, Vihara merupakan tempat beribadah untuk umat Buddha. umumnya tidak memiliki banyak rupang/patung.

2. Sudah berkurangnya ketertarikan anak-anak keturunan Tionghoa untuk mempelajari adatnya karena adatnya yang cukup rumit dipahami, dan anak zaman sekarang lebih suka sesuatu hal yang simpel.

3. Menurut Pembina kelenteng, Makanan persembahan melambangkan kita rela memberikan dana yang terbaik. Karena saat kita memberikan makanan atau buahan kepada dewa dan Buddha kita pasti memilih yang terbaik sebagai wujud kerelaan berbagi atau berdana.

4. Menurut penjaga kelenteng, Membawa persembahan ibaratnya seperti kita ke rumah orang lain, datang bertamu, bawa sesuatu sebagai tanda terima kasih serta rasa berterima kasih bahwa permohonannya telah terkabulkan. Persembahan dilakukan sebagai penutupan setelah kita melakukan sembahyang.

5. Persembahan dapat berbentuk buah-buahan, kue, biscuit, makanan kering, permen, minyak, bunga, dan terakhir kertas sembahyang. Karena kertas ini sama seperti "uang" sebagai tanda terima kasih.

6. Dewa populer di kepercayaan Tionghoa adalah Kwan Im. Selain Kwain Im paling Kwan Kong yang terkenal.

7. Dewa Kwan Kong populer dengan sikap ksatria dan kesetiaannya. Kwan Kong adalah Dharmapala/pelindung Dharma dalam tradisi Tiongkok. Salah satu sifat istimewa Kwan Kong adalah jiwa setia, ksatria, berani membela yang lemah dan tertindas. Tokoh dari kisah tiga negara banyak yang menjadi dewa pujaan bangsa Tionghoa.

\section{Hasil Visual \\ Sinopsis cerita}


Animasi pendek "Kwan" menceritakan tentang anak kecil bernama Tian-Tian yang sedang berkunjung ke kelenteng. Kemudian, Tian-Tian kelaparan sehingga ia memiliki keinginan untuk mencuri kue persembahan dewa Kwan. Namun tanpa disangka patung dewa Kwan dapat bergerak dan mencegah Tian-Tian untuk mecuri. Dewa Kwan menggunakan kekuatannya untuk memberikan pelajaran bagi anak kecil untuk tidak mencuri, dan juga untuk menghargai dewa di kelenteng.

\section{Penulisan judul Kwan}

Judul animasi pendek ini adalah "Kwan" karena merupakan nama karakter dewa dan seluruh visual animasi yang didasari dari kelenteng dimana dewa Kwan berada. Sesuai hasil riset observasi, kaligrafi China digunakan sebagai penulisan nama kelenteng. Selain itu, banyak referensi judul animasi dengan budaya Tionghoa menggunakan font kaligrafi untuk memberikan gambaran atas budaya yang digunakan. Font kaligrafi yang digunakan perancang sebagai judul adalah Dry-Brush. Font ini perlu di desain ulang agar lebih menyerupai tulisan kaligrafi China. Perancang juga menambahkan pedang Dewa Kwan di huruf K sebagai unsur visual yang penting ke dalam judul. Huruf pada font memiliki baseline yang tidak rata sehingga bersifat lebih naif, tidak kaku dan natural, yang cocok untuk film animasi dengan target audience anak-anak.

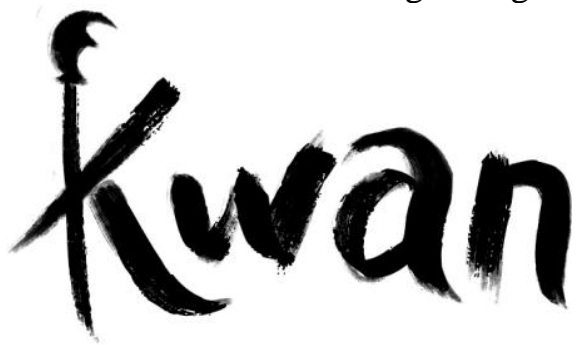

Gambar 5 Judul film animasi pendek Kwan

\section{Perancangan tokoh karakter}

Karakter dewa Kwan merupakan interpretasi dari Guan Yu, dewa perang di kepercayaan Tionghoa. Di Indonesia, Guan Yu lebih dikenal sebagai Kwan Kong (lord Guan), yang menjadi dasar nama Kwan. Kwan adalah dewa pelindung kelenteng serta penjaga kedamaian dan harmoni. Secara visual, bentuk dasar Kwan adalah lingkaran agar terlihat ramah, yang digabung dengan segitiga agar karakter lebih terlihat kuat, kokoh, dan mendukung gerakannya yang cepat.

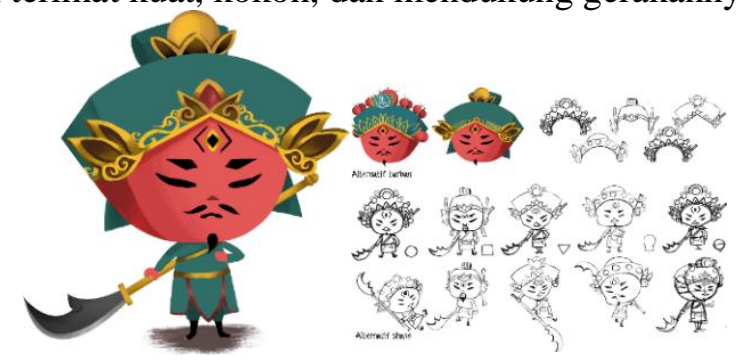

Gambar 6 Konsep karakter Kwan

Warna pakaian pada karakter dewa Kwan tidak hanya berasal dari image chart, tetapi tentu memiliki arti. Warna pakaian Kwan dominan warna hijau untuk menunjukkan kedamaian, ketenangan dan kerhamonisan yang dimana cocok karena Kwan merupakan dewa penjaga kedamaian dan harmoni. Warna kuning dalam color harmony analogous dengan warna hijau sehingga cocok sebagai ornamen. Ide wajah merah Kwan merupakan representasi dari opera China, wajah merah melambangkan kesetiaan dan kebenaran. Kwan Dao adalah jenis senjata tombak China yang digunakan dalam beberapa bentuk seni bela diri China. Dalam bahasa Tionghoa, Kwan Dao disebut Yue Dao Yan yang artinya "reclining moon blade".

Karakter lain dalam animasi ini adalah anak kecil bernama Tian-Tian. Tian-Tian adalah anak kecil yang tidak bisa diam. Ia penuh dengan rasa ingin tahu dan tidak takut melakukan 
apapun demi mendapatkan hal yang ia inginkan, terutama kue. Oleh karena itu, orang tuanya memanggilnya Tian-Tian yang artinya manis. Secara visual, bentuk dasar Tian-Tian adalah lingkaran karena sebagai anak-anak, ia harus terlihat ceria, lucu, dan friendly.

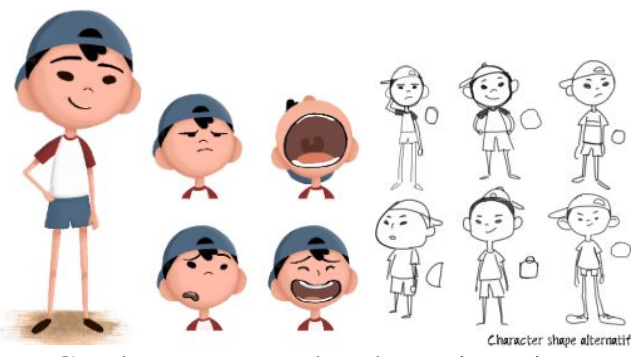

Gambar 7 Konsep karakter Tian-Tian

Anak laki-laki keturunan Tionghoa cenderung memiliki rambut yang pendek dan bewarna hitam. Dapat dilihat dari image chart, banyak film maupun animasi dengan karakter anak kecil khususnya Tionghoa menggunakan topi untuk menambah kemenarikan pada karakter.

\section{Environment}

Salah satu dan Environment utama penulis di dalam film animasi ini adalah kelenteng. Warna yang dipilih dalam mendesain kelenteng adalah kuning, merah dan hijau. Hal ini dikarenakan warna dominan pada kelenteng pada umumnya adalah ketiga warna ini. Warna dianggap penting dalam budaya dan kepercayaan etnis Tionghoa karena memiliki arti, terutama ketiga warna ini. Kuning menyimbolkan tanah dan memiliki arti kesetiaan dan kekuatan. Merah menyimbolkan api dan memiliki arti kebahagiaan, keberuntungan, dan kesuksesan. Hijau adalah warna yang memiliki arti kekayaan, harmoni, pertumbuhan, dan harapan.

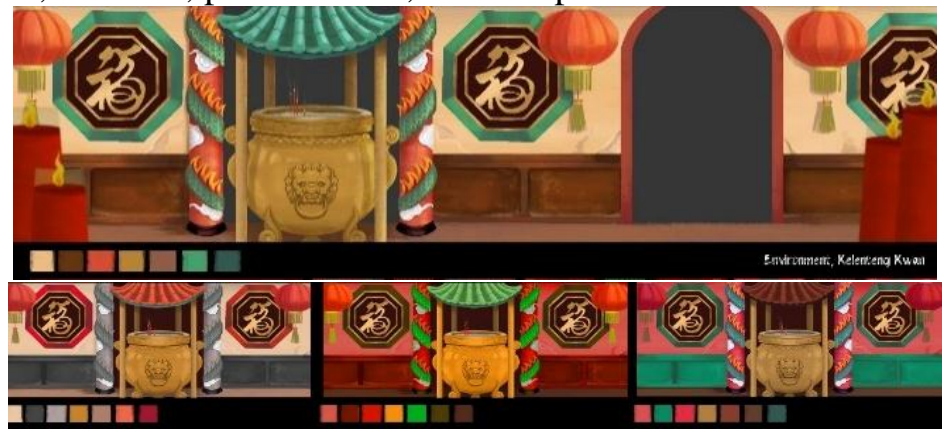

Gambar 8 Environment Kelenteng

Latar di dunia lain mengambil referensi dari lukisan China. Penulis juga melihat referensi dari film animasi serupa dan ilustrasi. Penulis menentukan dunia lain berbentuk outdoor sehingga banyak aksi yang dapat dilakukan kedua karakter. Pemilihan warna berbeda dengan kelenteng sehingga penonton mengetahui perbedaan latar yang drastis.

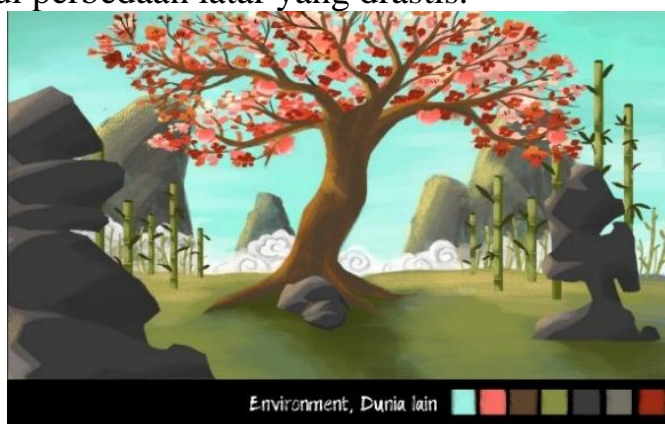

Gambar 17 Environment dunia lain 


\section{Pose}

Penulis menaruh beberapa syarat sebagai referensi dan syarat utama saat membuat film animasi Kwan. Berikut ini hasil desain pose:

1. Arc dalam animasi cartoony dapat diterapkan di gerakan dan pose untuk menambahkan keindahan. Arc ada di dalam gerakan realistik dan dunia nyata, namun di cartoony arc lebih terlihat dan exagerrate karena lebih mengutamakan estetika. Penting untuk menaruh Arc ke dalam pose agar lebih exaggerate dan indah, yang dimana merupakan syarat penting dalam membuat animasi dengan gerak cartoony. Selain keindahan, arc dapat menambahkan prinsip animasi exaggeration ke dalam pose. Berikut ini hasil sketsa peletakan arc di dalam pose:

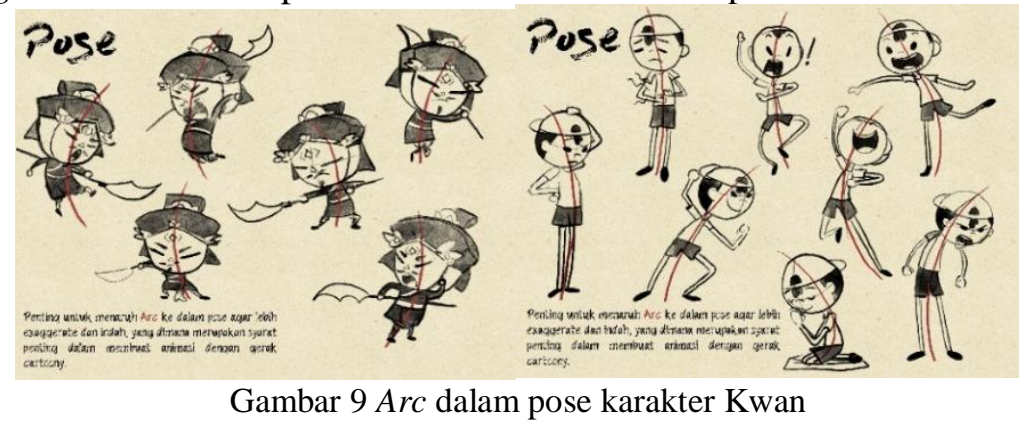

2. Arc di dalam animasi tidak hanya ada di dalam pose, namun juga gerakan, berikut ini hasil contoh arc di dalam gerakan:

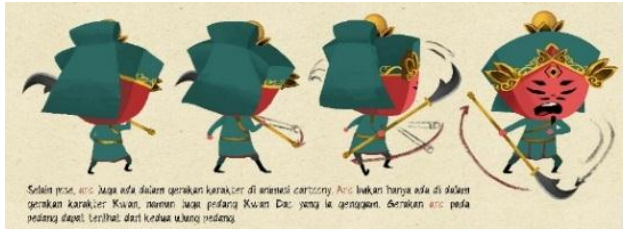

Gambar 10 Arc dalam gerakan karakter Kwan

3. Dalam membuat pose dan key animasi cartoony, penting memasukan squash \& stretch ke dalam gerakan. Squash \& stretch berperan penting dalam gerak animasi cartoony dan untuk menambahkan exaggeration. Biasanya squash \& stretch banyak digunakan sebagai pose inbetween. Squash \& stretch memberikan efek gerak yang lebih hidup.

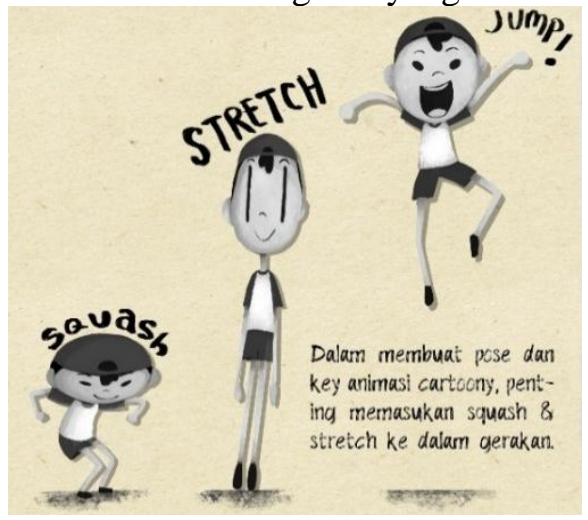

Gambar 11 Squash \& stretch dalam gerakan karakter Tian-tian

Siluet penting di dalam animasi untuk memperjelas pose. Negative space antara karakter Kwan dan pedang akan menambah kejelasan pose karakter dan memperjelas posisi pedang, sehingga secara siluet pun penonton dapat membedakan karakter dan letak pedang. Secara siluet pose karakter Tian-Tian akan memiliki lebih banyak negative space untuk memperjelas siluet serta karakternya yang periang dan aktif. 


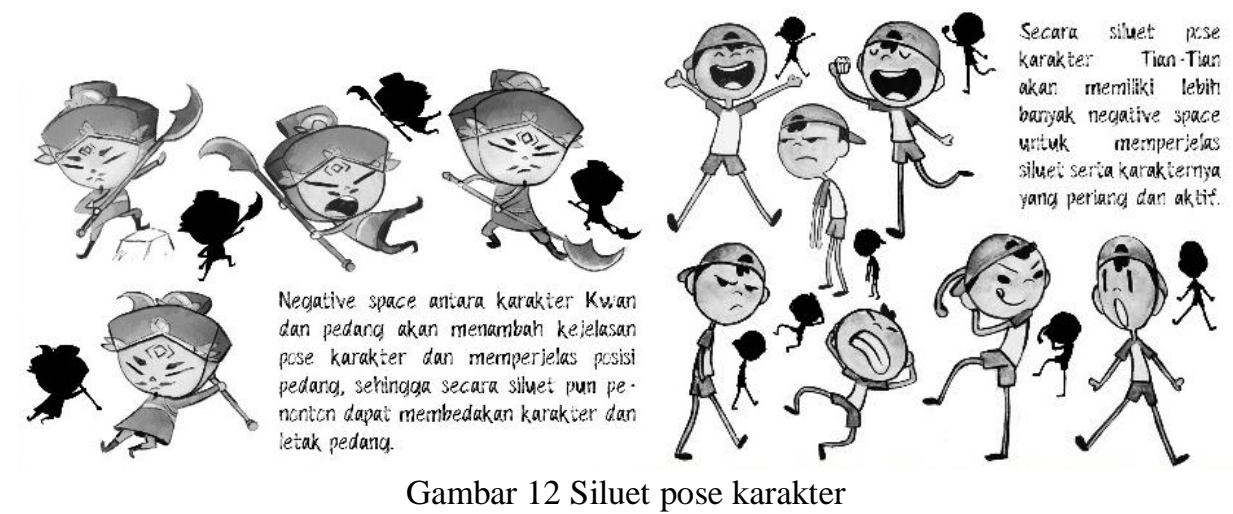

\section{SIMPULAN}

Ide utama penulis melakukan riset ini adalah untuk mempelajari lebih dalam gerak cartoony di animasi 3D. Penulis akan merancang latar belakang menggunakan 2D serta render animasi 3D menggunakan toon render. Hal ini dikarenakan, dalam gerak animasi step, cocok jika menggunakan toon render sehingga memiliki tekstur seperti 2D. Animasi 3D dengan tekstur 2D yang menggunakan animasi step cukup populer belakangan ini Spookiz, Umio, dan Hedgehog. Setelah mempelajari secara mendalam style gerak dan teori desain yang diterapkan ke dalam animasi, penulis dapat memulai merancang konsep desainnya. Walaupun animasi step belum dapat dibuat karena masih pengerjaan workbook, setidaknya penulis telah memiliki desain pose dan gerak yang sesuai dengan style gerak animasi cartoony dengan stepped key.

Untuk tema cerita, penulis akan mengangkat unsur-unsur budaya dan tradisi dari etnis Tionghoa sebagai inspirasi cerita. Alasan penulis memilih tema ini dikarenakan belum pernah ada film animasi dari Indonesia yang merepresentasikan budaya dan tradisi dari etnis Tionghoa. Dari segi visual, penulis akan mengambil referensi dari kuil dan patung di kelenteng, serta referensi style visual 2D yang cocok untuk gerak cartoony yang menggunakan stepped key. Oleh karena itu, penelitian ini bertujuan untuk mempelajari gerak cartoony sebagai perancangan di dalam film animasi pendek bertema tradisi dan budaya Tionghoa.

\section{DAFTAR PUSTAKA}

Ambrose, G., \& Harris, P. (2010). Basic design 08: design thinking. Switzerland: AVA Publishing SA.

Ansara, R. (2015). Adding Cartoon-Like Motion to Realistic Animations: Thesis submitted to the Faculty of Graduate and Postdoctoral Affairs. (thesis Master of Applied Science). Carleton University Ottawa, Ontario, Canada.

Catmull, E. (1972, August). A system for computer generated movies. In Proceedings of the ACM annual conference-Vol. 1 (pp. 422-431). ACM.

Fernandez, I. (2001). Macromedia flash animation \& cartooning: A creative guide. New York: McGaw-Hill Companies.

Hwang, I., Tam M., Lam S. L., \& Lam P. (2012). Review of use of animation as a supplementary learning material of physiology content in four academic years. The Electronic Journal of e-Learning, 10(4), 376.

Lasseter, J. (1987). Principles of traditional animation applied to $3 d$ computer animation. New York: ACM. 
Pluralsight. (2014, Juli 7). Stepped Vs. Spline Curves When Blocking an Animation. Diakses dari: https://www.pluralsight.com/blog/film-games/stepped-vs-spline-curves-blockinganimation.

Strippedpixel. (2013, Oktober 28). Know Your Gods: Guan Yu. Diakses dari: http://www.strippedpixel.com/guan-yu-chinese-god/.

Thomas, F., \& Johnston, O. (1981). Disney animation: The illusion of life. United States: Abbeville Press.

Undang-Undang Nomor 12 Tahun 2006 tentang Kewarganegaraan Republik Indonesia.

Whitaker, H., \& Halas, J. (1981). Timing for animation. London: Focal Press.

William, R. (2009). The animators survival kit. London: Faber. 